\title{
FEW NOTES ON MEASURES TO PREVENT TAX EVASION AND TAX FRAUD - WHAT IS THE INTEREST OF SOCIETY? ${ }^{1}$
}

\author{
Ivana Štieberová ${ }^{2}$
}

\begin{abstract}
Tax evasion is a very serious and dangerous problem. In recent years, therefore, several measures have been taken to prevent it. The aim of this paper is to determine whether the measures taken to prevent tax evasion are sufficient and whether it is possible, or even more effective, to achieve the intended purpose - to reduce tax evasion to the lowest possible level by other means that shall not burden the taxable entities and will therefore not only for the benefit of state but also for the benefit of taxable entities. We will focus mainly on the moral aspects of preventing tax evasion. We conclude that in the area of tax relations there is a quite significant correlation between legal consciousness and morality. Few problems in society are as sensitive as the relationship of taxable entities to the state or the local government authority in relation to the fulfillment of tax obligations.
\end{abstract}

\section{Key words}

Reduction of public budget revenues; tax law; tax evasion; tax compliance

\section{JEL Classification: H26, K34, K42}

\section{Introduction}

Each State seeks to secure as many funds as possible into the state budget, which are allocated there and subsequently serve to cover the needs of the society which cannot be provided through the operation of the market mechanism. Undoubtedly,

\footnotetext{
1 This article represents a partial output of the grant projects VEGA 1/0846/17: "Implementation of the initiatives of the EU institutions in the field of direct taxes and indirect taxes and their budgetary law implications" and APVV-16-0160: "Tax evasion and tax avoidance (motivation factors, formation, and elimination)".

2 Internal Ph.D. Student, Department of Financial Law, Tax Law and Economy, Faculty of Law, Pavol Jozef Šafarik University in Košice, Slovak Republic. Contact email: ivana.strakova1@student.upjs.sk.
} 
the most important source of the state budget revenues is taxes. Tax revenues represent $75-80 \%$ of the total state budget revenues each year. This revenue side of the state budget is under threat in case the tax evasion occurs. Generally speaking, tax evasion can be considered as tax non-payment in violation of the law (Babčák, 2015: 100).

Tax evasion thus represents a dangerous and serious problem from the economic and fiscal perspective. In the past, paying taxes belonged to and currently belongs to one of the least-favorite activities of taxable entities. There is probably no commercial entity that does not want to minimize its own tax burden.

The highest number of tax evasion and tax fraud may be noticed in the area of value added tax (hereinafter referred to as "VAT"). For this reason, this area is being given the greatest attention, various analyzes are being produced, and the controlling activity focuses mostly on this area. In October 2016, the Financial Policy Institute of the Ministry of Finance of the Slovak Republic (hereinafter referred to as "SR") produced an analysis of operation of the financial administration of the Slovak Republic of October 2016 (Inštitút finančnej politiky Ministerstva financií SR, 2016) where they claim that, according to current estimates, the VAT tax gap ${ }^{3}$ in the year 2015 reached $29.2 \%$ of the potential VAT in the Slovak Republic. In nominal terms, this difference corresponds to 2.2 billion euros, representing $2.8 \%$ of GDP. The European Commission argues that VAT Gap in the European Union (hereinafter referred only as "EU") in 2014 was nearly 160 billion euros lost in uncollected revenues.

It is therefore understandable that states are trying to take measures to prevent tax evasion and tax fraud, to make them as small as possible and thus to make the tax gap as small as possible as well. Therefore, on the territory of the Slovak Republic, successive amendments were drafted to the individual tax legislation, various measures were taken and new institutes were set up to help detect and combat tax evasion. This paper will focus primarily on measures taken to prevent tax evasion and tax fraud on VAT.

Surely, such measures are necessary and several of them have helped achieve the intended purpose of discouraging taxable entities from committing tax evasion. However, it is necessary to take into consideration for how long it is possible to impose new obligations on taxable entities, burdening them with new measures to combat tax evasion, which represent a further administrative burden for them in most cases. estimate of revenue loss due to tax fraud, tax evasion and tax avoidance, but also due to bankruptcies, financial insolvencies or miscalculations. 
Few Notes on Measures to Prevent Tax Evasion and Tax Fraud - What is the...

The aim of this paper is to determine whether the measures taken to prevent tax evasion are sufficient and whether it is possible, or even more effective, to achieve the intended purpose - to reduce tax evasion to the lowest possible level by other means that shall not burden the taxable entities and will therefore not only for the benefit of state but also for the benefit of taxable entities. We will focus mainly on the moral aspects of preventing tax evasion.

In this scientific paper, we will use several scientific methods. Firstly, a systematic and a descriptive method will be used. Also abstraction as an inevitable form of scientific thinking (Knapp, 2003: 65-67). Analysis and synthesis will also be applied, especially in the analysis of selected institutes aimed at preventing tax evasion (such as tax audit and control statement). Of course, we will use a method of induction as a process from special to general. The comparative method will be applied as well. Each method will be used in combination with each other, because only then can we achieve the aim of this paper.

\section{A Few Notes About Institutes and Measures to Prevent Tax Evasion and Tax Fraud}

Many taxable entities (especially "small entrepreneurs") do not consider the measures that are being taken in the area of combating tax evasion in a positive sense. In the event of adopting a measure (for example, some time ago guaranteeing for the value-added tax, a control statement ${ }^{4}$ ) in order to prevent and detect tax evasion and tax fraud, although it is essentially an effective tool to tackle this dangerous issue, such a measure has ultimately an impact on small and medium-sized enterprises that are "paying a price" for it (for example, there is the administrative burden they feel to a greater extent than bigger entrepreneurs).

Take, for example, the control statement. The importance of introducing the VAT control statement is that it represents an important source of information for financial administration. It was introduced for the purpose of cross-checking those data which are subject to VAT and where the tax liability incurs in the Slovak Republic. Due to content of the control statement, that is, the data that the taxpayers are obliged to state, it may be said that it is to serve the tax administrators for the purposes of early detection of risk entities suspected of tax evasion, to better a control of requests for refunding excess VAT deduction, also for early detection of domestic and cross-border carousel fraud and various machinations of invoices.

4 VAT control statement is a detailed summary of information on all VAT payer transactions subject to Slovak VAT. It is a form that is required to submit by each VAT payer in the SR and shall specify details of individual tax obligations of the VAT payer and the individual VAT deductions applied by the VAT payer for the relevant period. For more information, see below. Hereinafter referred to as "control statement". 
This means that the VAT control statement has a control function in taxable transactions within the SR, as well as the recapitulative statement has a control function in intra-community transactions within the EU. The data presented in it is based on tax return data, which are more detailed in the VAT control statement (Jarošová, 2014). The control statement, which is an effective measure to combat tax evasion ${ }^{5}$, represents another non-pecuniary obligation for the taxable entity (the VAT payer).

If we look on the individual measures (VAT guarantee, guaranteeing for the value added tax, control statement) purely from the fiscal point of view, the analysis prepared by the Financial Policy Institute of the Ministry of Finance of the Slovak Republic indicates that has been a VAT gap reduction by as much as one quarter by the measures adopted to prevent tax evasion compared to 2012, when it reached its peak. The reduction of the tax gap was mainly due to the streamlining of the control processes, while by streamlining the control processes we understand the fact that the financial administration of SR has gradually become more and more focused on the tax audits of excess deductions of the VAT. This is more important from the perspective of potential VAT revenues, as detection of fraud with excess deductions of VAT prior to their payment means net savings. On the contrary, in most cases (e.g. if the entity terminates its activities) the additional assessing of tax does not imply an increase in tax revenues.

However, if we look at it only from a fiscal, economic or legal point of view, it may be said that such a profoundly pro-fiscal approach may appear as a form of certain bullying by tax administrators and the state, because 'smaller' taxable entities (small and medium entrepreneurs) feel that large corporations are not affected as much as they are. Thus, the expected effect is different as it should be. This is related to situations where huge tax evasion has been detected, but the responsible entity was ultimately not punished.

\section{Tax Audit and Interest on VAT Refund}

As you may notice another effective tool in preventing tax evasion and tax fraud on VAT is a tax audit (Straková, 2016: 424-442). A tax audit is undoubtedly an effective tool in preventing tax evasion and taxable entities are obliged to tolerate the performance of the tax audit for a certain statutory period. But what if the tax audit exceeds this statutory time limit? What impact does it have on the status of

Only in 2014, based on data from the VAT control statement, were identified schemes of fraudulent behavior at 7,106 entities with a total amount of VAT of 213,044 million euro. However, this tool has also increased the effectiveness of VAT tax audits, namely the specific focus of tax audits. 
Few Notes on Measures to Prevent Tax Evasion and Tax Fraud - What is the...

the taxable entity? The problem arises, in particular, when the payment of taxable entity's funds, such as excess deduction of the VAT, depends on the termination of the tax audit, which is legally carried out but takes longer than usual, and it is concluded that the taxable entity has requested the payment of the funds legally. The issue had arisen due to the context of tax audit performance to verify rightfulness of the claim to refund an excessive VAT deduction or its part and therefore, following the decision of the Court of Justice of the EU of 21 October 2015 in case C-120/15 Kovozber, an interest on VAT refund ${ }^{6}$ has been incorporated into our legal system ${ }^{7}$ since 1 January 2017.

Interest on VAT refund represents a certain compensation for the taxable entity in case the refund of excess VAT deduction was made after the tax audit which exceeded a reasonable period of time ${ }^{8}$. However, it was introduced only on the basis of the decision of the Court of Justice of the EU, which stated in its resolution that "provided the excess VAT deduction is refunded to the taxable person after the expiry of a reasonable period, the principle of fiscal neutrality requires that the financial losses thus incurred to the taxable person, which results from the impossibility of disposing of such amounts, were compensated by the payment of default interest".

The trend among the tax administrators has become the situation in which the taxable entity claims the refund an excess VAT deduction, they initiate the tax audit to verify rightfulness of the claim to its refund ${ }^{9}$, which results from the fact that in recent years there was a huge tax evasion and tax fraud in connection with the unjustified application of excess VAT deductions by taxable entities (VAT payers).

However, if the taxable entity claims the refund of excess VAT deduction rightfully ${ }^{10}$, as demonstrated at the completion of the tax audit, there is a large intervention in the sphere of property of the taxable entity. During the tax audit verifying the rightfulness of the claim to refund an excessive VAT deduction or its part, the taxable entity cannot dispose of funds corresponding to the applied excess deduction. This follows from the fact that if the tax office (the tax administrator) initiate the tax audit within the time period for refunding the excess deduction, the

6 For more details on introducing this interest into our legal order, see for example Bonk (2016: 40-52).

7 Its regulation is in Act No. 222/2004 on Value Added Tax in the wording of later regulations (hereinafter "VAT Act") in Art. 79a "Compensation for VAT refund retained during tax audit".

8 For the length of the tax audit, Cf, for example, Vernarský (2012: 48-60); also Štrkolec (2014: 1354-1363).

9 The annual report of the Financial Administration for 2016 shows that until December 31, 2016, were carried out entirely 7288 tax audits of excess deductions of VAT, which represent $80.4 \%$ of the total tax audits on VAT and $61.6 \%$ of the total number of tax audits carried out on all types of taxes.

10 The taxable entities often try to get the claim of excess VAT deduction by means of various camouflage legal acts. For camouflage legal acts, their difference against an abuse of law and a circumvention of the law, see more e.g.: Popovič (2016: 255-265). 
tax office shall refund the excess deduction within ten days of the completion of the tax audit in the amount determined by the tax office, except for the return of a portion of the excess deduction based on the interim protoco ${ }^{11}$. Thus, it may be observed that if the taxable entity claims a refund of the excess VAT deduction in the relevant taxation period and the tax audit is initiated, there is in some cases a significant extension of the deadline for refund of the excess deduction, namely twelve (or twenty-four months) and even if the tax audit is interrupted, it may also take a longer period of time.

It may be noted that the taxable entity has a primarily fiscal interest in a rapid termination of the tax audit in order to be able to dispose of the funds corresponding to the claimed excess VAT deduction. In many cases, this is not a negligible amount, and the non-payment of excess VAT deduction may be liquidated for the taxable entity. They count on a certain income to be able to continue to pay their liabilities. Of course, it is the right of the tax administrator, in case of doubt, to verify whether the taxable entity applies excess VAT deduction rightfully. However, it is not conceivable for the state to do so whenever a taxable entity asks for the refund of the excess VAT deduction. It affects mainly honest entrepreneurs because the tax administrator is mostly trying to reject the excess VAT deduction or reduce it as much as possible by referring to the general principle of the prohibition of abuse of law ${ }^{12}$, which applies to the area of tax law as well. Retention of excess deduction by the tax administrator in case the subsequent tax audit proves that the claim to refund an excessive deduction or its part was rightful, has a significant interference to the taxable entity's financial freedom and to the violation of VAT neutrality.

Here, it can be noticed, in the case of the tax audit to verify the rightfulness of the claim to refund excess VAT deduction, there is a conflict between the rights of the audited taxable entity which tries to minimize its own tax burden and the fiscal interests of the state or municipality.

The introduction of interest on VAT refund seems to be a significant measure in the interest of the taxable entity, but its regulation in our legal order is not satisfactory. Value Added Tax. The tax administrator could return a portion of the excess deduction before the end of the tax audit in the amount defined in the interim protocol. In particular, this concerns the situations where during the tax audit the tax administrator finds out that a portion of the excess deduction is rightfully applied, but for the remaining portion is needed further investigation, such as getting information through an international exchange of information from another Member State of the European Union, which sometimes takes a long time and therefore it is not possible to terminate tax audit.

12 To introduce this principle into our law, see for example Prievozníková (2015: 161-168); also Sábo (2015: 199207); also Románová (2015: 212-228). 
Few Notes on Measures to Prevent Tax Evasion and Tax Fraud - What is the...

In particular, when regarding the period from which the taxable entity is entitled to such interest $\mathrm{t}^{13}$ and its amount $\mathrm{t}^{14}$.

\section{Tax Compliance as a Tool to Eliminate Tax Evasion?}

Based on the above, it can be stated that the measures taken to prevent tax evasion and tax fraud from the economic and fiscal point of view represent effective measures to prevent tax evasion. Even by the above-mentioned measures, the VAT gap was reduced. If we compare it to the average level in the EU, there is still considerable scope for continuing the fight against tax evasion and tax fraud so far.

As E. Kirchler claims that "tax evasion is a complex phenomenon which is influenced not just by economic motives but by psychological factors as well". In the search for answers to questions on how to prevent tax evasion, it cannot be viewed only from a fiscal point of view, but also from a moral point of view ${ }^{15}$, which is important from the perspective of the individual. Therefore, to find a way to persuade taxable entities to comply with tax regulations, thus not committing tax evasion. Constant audits and fines may cause opposite effects than ensuring compliance. On the contrary, it may interfere with the voluntary compliance (Kirchler, 2009). Although we understand that, at a time when extensive tax evasion occurred, in particular through the unjustified application of excess VAT deductions, it was understandable that tax administrators have carried out tax audits to verify rightfulness of the claim

13 An entitlement to the interest on VAT refund arises if the tax office initiates the tax audit within the time period for refund of the excess VAT deduction and the VAT refund is not paid within six months from the last day of the time period for refund of the excess deduction. This entitlement arises only since the first day after the expiration of the six-month period and is counting until the day of the retained VAT refund. It is apparent from the explanatory memorandum that the legislature modified the entitlement to interest on VAT refund in such a way as to leave the State some time to exercise its power to control the rightfulness of the excess deduction without the entitlement to interest on VAT refund for this period. Interestingly, the taxable entity does not have such a time when he is late with the payment of the tax and is liable to pay interest on late payment. Moreover, the Court of Justice of the EU state that the taxable entity is entitled to interest on refund of excess VAT if the excess VAT deduction is refunded to the taxable entity after the completion of the tax audit which exceeded the reasonable time period and as the starting point should be taken the date on which the excess VAT would have had to be repaid in the normal course of events. It is therefore questionable whether the legislation adopted in the Slovak Republic and in force since 1 January 2017 is in line with what the Court of Justice of the EU. In our opinion, this is not the case, and that the regulation of interest on VAT refund should be defined in the law simpler and more comprehensible and interest on VAT refund should be granted earlier, from the moment when it should normally be returned under the VAT Act.

14 The interest on VAT refund shall be granted in the amount equal to double the European Central Bank interest rate valid on the first day of the calendar year for which the interest is charged. Also if the interest rate of the European Central Bank is below $1.5 \%$, a minimum interest rate is $1.5 \%$. At this point, we would like to note that if the taxable entity is late with the payment of the tax (or other amounts within the meaning of Article 156/1 of the VAT Act), he is obliged to pay interest on delayed payment, which is set at multiple of four of the base interest rate of the European Central bank valid on the date when the tax arrears arose, while if the multiple of four of the base interest rate of the European Central Bank does not reach 15\%, the annual interest rate of $15 \%$ shall be applied. The state is required to pay interest at the rate of $1.5 \%$ and the taxable entity who is late with the payment of the tax interest at the rate of $15 \%$.

15 These connections between taxation, tax evasion and tax compliance is highlighting by several authors. See for example Bujňáková (2015: 61). 
to refund an excessive VAT deduction (or its part) to detect such a breach of tax regulations. However, it is inconceivable that they initiate the tax audit every time the taxable entity asks for a refund of the excess VAT deduction.

Rather than guaranteeing compliance, audits and fines may have opposite effects in a trustful climate and thus corrupt voluntary compliance. Cooperation is essential and such cannot be there without trust. But trust can go downwards to reduced levels when authorities respond to low levels of cooperation with control and punishment. Such an approach consisting of audits and imposing fines may be effective in a completely distrustful climate with the high social distance between authorities and taxpayers. In such a climate with no voluntary compliance, compliance may be enforced by the power of the authorities. However, audits and fines as "the tools" to command and control taxpayers will not be suitable to create a cooperative tax atmosphere (Kirchler, 2009).

In creating a trust between tax administrator and taxable entity, not only the behaviour of the taxable entity is important, but also the behaviour of the tax administrator so that he does not abuse the tax regulations and excessively burden the taxable entity as it happened, for example, in the case of constantly carrying out tax audits to verify rightfulness of the claim to refund an excessive VAT deduction or its part.

In the inspection of the compliance with tax obligations (e.g. within tax audit), tax administrators control small entrepreneurs without focusing on large taxable entities. This is also not supported by the mass media, where there are often various headlines that point to such situations. On the one hand, it is good because we cannot turn a blind eye to such situations and it is necessary to draw attention to them, but for some people this can lead to or encourage a belief that taxes are not necessary, or to raise various questions, especially why they have to pay taxes, when other subjects do not pay taxes and are not sufficiently punished.

\section{Conclusions}

It can be observed that the measures taken to prevent tax evasion are fiscally and legally effective but not sufficient. It is, therefore, necessary to find new ways to prevent this dangerous social phenomenon where, in our opinion, it shall become important in the future to focus on the ethical aspects and the combination of these economic, fiscal, legal and moral measures to find the most effective ways to prevent tax evasion. 
Few Notes on Measures to Prevent Tax Evasion and Tax Fraud - What is the...

Taxpayer's decision whether or not to pay taxes represents a social dilemma where private and communal interests go against each other, as paying taxes is costly for individuals but benefits society: taxation is strongly linked to the provision of public goods and services. These goods governments usually provide for the general public because private individuals would not provide an efficient level of public goods. Taxes are necessary to finance the public provision of these goods and services. Therefore, it seems natural that tax compliance is affected by the quality of publicly provided goods and services. ${ }^{16}$ Experiments have shown that a higher return from public goods leads to increased tax compliance (Blackwell, 2007). Social effects have been widely explored in the laboratory using public good experiments. Tax compliance experiments have tested and confirmed these effects.

Taking into account a moral and psychological point of view, it may be stated that the process of identifying with the fairness of taxation objectively takes decades, and any negative signal from the incorrect use of taxes may disturb it. The taxable entity, in order to believe the meaningfulness of paying taxes, cannot be disturbed and confronted with frequent social annoying phenomena and undesirable practices such as high corruption, a widespread black economy and politicizing management of tax policy, at the expense of stability, maximum expertise, and independent professionalism.

Tax reforms that work on the principle and basis of friendly taxation should dominate in practice. Its essence is based on the fact that the taxable entity is better to be persuaded than coerced. It is related to the ever stronger connection of the economy with psychology. The confidence of the taxable entity to the tax administrator (state) in order to increase the rate of voluntary payment of taxes is achieved by coordination rather than confrontation. If the state fails to do so, it evokes counterproductiveness (thus provoking taxable entities to tax non-discipline, circumvention of tax laws, tax avoidance and other forms of tax evasion) (Burák, 2013).

From the problems and reserves, the tax administrators predominantly have huge reserves in the quality of tax services and at the same time the insufficient level of tax sharing and legal awareness of most taxable entities. It is necessary to increase financial literacy and the related improvement and support of tax education for taxable entities through educational programs for the general public, including in the mass media.

In conclusion, the science of tax law does not pay attention to the research of the relationship between tax law, tax legal awareness, and tax morality. It can be said that in the area of tax relations there is the quite significant correlation between 
legal consciousness and morality. Few problems in society are as sensitive as the relationship of taxable entities to the state or the local government authority in relation to the fulfillment of tax obligations. In relation to commercial entities, this may be extended to fulfill any obligations towards mentioned authorities (in particular, the payment of social security, health insurance, etc.). Research and evaluating of tax legal awareness of society and the related problem of tax morality is thus much more substantial and important than it might seem and also it is important in preventing tax evasion.

\section{References}

Babčák, V.: Daňové právo na Slovensku (Tax law in Slovakia), Bratislava: EPOS, 2015.

Blackwell, C.: A Meta-Analysis of Tax Compliance Experiments, Georgia: Andrew Young School of Policy Studies, Georgia State University, 2007.

Bonk, F.: Fiskálny záujem štátu verzus dížka trvania daňovej kontroly (Fiscal state interest vs. length of the tax audit), in: Mrkývka, P., Czudek, D., Valdhans, J. (eds.): Dny práva 2015 - Days of Law 2015, Brno: Masaryk University, 2016.

Bujňáková, M.: Niekol'ko poznámok k téme daňových podvodov (A few notes about tax fraud), in: Babčák, V., Románová, A., Vojníková, I. (eds.): Tax Law vs Tax Frauds and Tax Evasion: non-conference proceedings of scientific papers, Košice: Pavol Jozef Šafarik University in Košice, 2015.

Burák, E.: Daňová politika a daňová ilúzia (Tax policy and tax illusion), Daňový špeciál (Tax special) no. 3 (2013).

Červená, K., Hučková, R.: Náčrt príčin (ako východísk pre kreovanie opatrení) v kontexte eliminácie daňových únikov (Outline the reasons (as starting points for creating measures) in the context of the elimination of tax evasion), in: Babčák, V., Románová, A., Vojníková, I. (eds.): Tax Law vs Tax Frauds and Tax Evasion: non-conference proceedings of scientific papers, Košice: Pavol Jozef Šafarik University in Košice, 2015.

Inštitút finančnej politiky Ministerstva financií SR (The Financial Policy Institute of the Ministry of Finance of the SR), Analýza prevádzky Finančnej správy SR "Výber daní z našich daní (An Analysis of Operation of the Financial Administration of the Slovak Republic "Collection of Taxes from Our Taxes"), 2016. www.finance.gov.sk.

Jarošová, B.: Kontrolný výkaz na DPH - nová povinnost' pre platitel'ov od 1.01.2014 (VAT control statement - a new obligation for VAT payers from 1 January 2014), Dane a účtovníctvo (Taxes and accounting) no. 1 (2014).

Kirchler, E.: The Economic Psychology of Tax Behaviour, New York: Cambridge University Press, 2009.

Knapp, V.: Vědecká propedeutika pro právníky (Scientific propaedeutic for lawyers), Praha: Eurolex Bohemia, 2003. 
Few Notes on Measures to Prevent Tax Evasion and Tax Fraud - What is the...

Popovič, A.: Zastierané právne úkony pri správe daní (Camouflage of legal action in the tax administration), in: Popovič, A., Románová, A., Straková, I. (eds.): Abuse and Other Forms of Circumvention of Law: reviewed proceedings of scientific papers, Košice: Pavol Jozef Šafárik University in Košice, 2016.

Prievozníková, K.: Implementácia zákazu zneužitia práva do daňového poriadku (Implementation of prohibition of abuse of law to the Tax Procedure Code), in: Babčák, V., Románová, A., Vojníková, I. (eds.): Tax Law vs Tax Frauds and Tax Evasion: non-conference proceedings of scientific papers, Košice: Pavol Jozef Šafarik University in Košice, 2015.

Románová, A.: The new anti-abuse rule in Slovak tax law: Strengthening of legal certainty? in: Radvan, M. (ed.): System of Financial law: System of Tax Law, Brno: Masaryk University, 2015.

Sábo, J.: GAAR (všeobecné pravidlo predchádzania daňovým únikom) v právnom poriadku SR (GAAR (general rule preventing tax evasion) in the law of the Slovak Republic), in: Babčák, V., Románová, A., Vojníková, I. (eds.): Tax Law vs Tax Frauds and Tax Evasion: non-conference proceedings of scientific papers, Košice: Pavol Jozef Šafarik University in Košice, 2015.

Straková, I.: Právne aspekty daňovej kontroly ako nástroja slúžiaceho na elimináciu daňových únikov (Legal aspects of tax audit as a tool to prevent tax evasion), in: Mrkývka, P., Czudek, D., Valdhans, J. (eds.): Dny práva 2015 (Days of Law 2015), Brno: Masarykova univerzita, 2016.

Štrkolec, M.: Prerušenie daňovej kontroly - prípustnost', dôsledky a možnosti procesnej obrany (Interruption of a tax audit - admissibility, consequences and possibilities of a procedural defense), Justičná revue (Judicial review) no. 11 (2014).

Vernarský, M.: Limity daňovej kontroly (Limits of tax audit), Justičná revue (Judicial review) no. 1 (2012).

EU: Court of Justice of the European Union: C-120/15. 